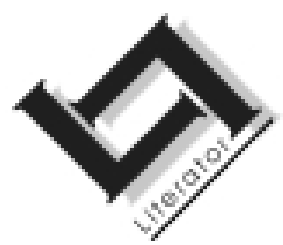

\title{
Reclaiming lost ground - the history play in Zulu
}

\author{
H.C. Groenewald1 \\ Department of African Languages \\ Rand Afrikaans University \\ AUCKLAND PARK \\ E-mail: hcgr@Iw.rau.ac.za
}

\section{Abstract \\ Reclaiming lost ground - the history play in Zulu}

This article briefly sketches the history of African-language literatures as initiated by missionaries and formed by Bantu education. Against this background the aim of this article is to establish what the objectives of Zulu dramatists were when they presented historical fact, flawed history, as well as ideological sentiment in their historical plays. Are history plays in Zulu simply the products of writers whose objective was to meet a publisher's requirements, namely to extend the dramatic genre by writing history plays? Did authors perhaps only have an educational objective, that is, to provide learners with setwork material? If, on the other hand, the history play is the creation of a memory for a specific purpose, as post-colonial theorists suggest, the next objective of this article is to establish what kind of memory Zulu dramatists have created and for what purpose. The history plays will be discussed under the following topics: UNodumehlezi kaMenzi He who is famous as he sits, son of Menzi (King Shaka). In exploring aspects of Shaka's rule, it becomes clear that writers express their pain about the great loss the Zulu nation suffered when the Shakan era passed. The second topic treats Izwe lidungekile - The land is in turmoil. The dramas dealt with here vividly depict the pitiful state of the Zulu after their subjugation by the British empire, leading eventually to an inevitable option - armed resistance. The third and last topic, Izwe ngelethu - The land is ours - treats the issue of land.

1 Suggestions by Geoff Allen of the Department of Historical Studies, Rand Afrikaans University, are gratefully acknowledged. 


\section{Opsomming}

Die herwin van verlore waardigheid - die historiese drama in Zoeloe

Hierdie artikel skets kortliks die geskiedenis van Afrikataalletterkundes soos gestimuleer deur sendelinge en gevorm deur Bantoe-onderwys. Teen hierdie agtergrond is die doel van hierdie artikel om te bepaal wat die mikpunt van Zoeloe-dramaturge was in hul aanbieding van historiese feite, foutiewe geskiedenis, sowel as ideologiese sentiment in die skryf van historiese dramas. Is historiese dramas eenvoudig die produkte van skrywers wie se doel dit was om aan 'n uitgewer se vereistes te voldoen, naamlik om meer dramas die lig te laat sien? Het skrywers miskien 'n opvoedkundige doel gekoester, naamlik om leerders te voorsien van voorgeskrewe stof? Indien die historiese drama egter die rekonstruksie van geskiedenis of herinnering is vir 'n spesifieke doel, soos postkoloniale teoretici inderdaad suggereer, is die volgende taak van die artikel om te bepaal wat die aard van sodanige herinnering is en vir watter doel dit daar is. Die historiese dramas sal bespreek word na aanleiding van die volgende temas: UNodumehlezi kaMenzi - Hy wat sittend beroemdheid verwerf, seun van Menzi (Koning Shaka). In hul behandeling van aspekte van Shaka se bewind, word dit duidelik dat skrywers hul leed uitbeeld oor die groot verlies wat die Zoeloe-nasie gely met die verbygaan van die Shaka-era. Die tweede tema wat behandel word, is Izwe lidungekile - Die land is in rep en roer. Die dramas wat hier behandel word, beeld die jammerlike toestand uit waarin die Zoeloes hulself bevind het nadat hulle onderwerp is aan die Britse koninkryk. Hierdie situasie het gelei tot 'n onvermydelike keuse, naamlik gewapende opstand. Onder die laaste opskrif, Izwe ngelethu - Die land is ons s'n - sien ons hoe die kwessie van grondbesit behandel word.

\section{Introduction}

Initiated by missionaries (except for a few literatures) and forged by Bantu Education, literatures in African languages have always occupied a peculiar position among the literatures of South Africa. The religious intentions of the missionaries and the separate development envisaged for African languages and their literatures by the apartheid government saw to it that these literatures did not develop in an uninhibited manner, to say the least. In the light of these circumstances and the many disparaging views expressed on African language literatures (see Ntuli, 1987:127 for a short summary of these views), the question can rightly be asked: for what purpose have African language authors been writing books? For the purposes of this article one may ask the following questions: What were the intentions of Zulu dramatists? Were history plays in Zulu simply the products of writers whose objective it was to meet a 
publisher's requirements, namely to extend the dramatic genre by writing history plays? Were authors coerced into pursuing an educational objective, namely to provide learners with setwork material? The hypothesis of this article is that, despite the oppression of apartheid, dramatists were using (and misusing) history to criticise aspects of apartheid and to construct a memory while enacting historical moments.

\section{Theoretical background}

If "human memory is given to error, misconception from elision, distortion, elaboration and downright fabrication" (Minkley \& Rassool quoted in Nuttall \& Coetzee, 1998:91), the relationship between historical fact and the workings of memory is relevant. Studies on historical plays in a few African languages reveal immediately how relaxed, if not flippant, dramatists are toward historical fact in their plays. Concluding his study on Khaketla's historical plays, Phafoli (1996:171) says:

Thus Khaketla's plays are his reflections of history, not the way events actually happened. He has changed some of the characters and their actions so as to present his own views. He has also included some of the incidents which cannot be traced historically to avoid the historical constraints which would not have allowed him a freedom of expression as a playwright.

Zondi (1989:51) confirms that for Zulu dramatists “... some seem to have simply transformed into drama superficial historical views, often biased by prejudice". Portelli (quoted by Field, 2001:250-251) offers the following insight concerning historical fact in oral histories:

Oral sources are credible but with a different credibility. The importance of oral testimony may lie not in its adherence to fact, but rather in its departure from it, as imagination, symbolism, and desire emerge. Therefore, there are no 'false' oral sources ... The diversity of oral history consists in the fact that 'wrong' statements are still psychologically 'true', and that this truth may be equally as important as factually reliable accounts.

This attitude towards fact in oral histories provides, in my view, a reason for the apparent falsehoods and imaginations one may find in some historical texts, whether oral (izibongo, for instance) or written. Field (2001:253) refers to oral histories as the art of the possible because participants not only relate what really happened, and what might have happened, but also "fragments of a past desired". 
The historical drama in Zulu reveals the same attitude towards factuality as sketched above for oral history. The historical drama does not have as its primary objective the accurate recording of history. Historical fact has been used for other purposes. If one takes into account that historical dramatists were trying to make sense of the past under the pressures of the apartheid regime, it stands to reason that the past was used to comment on the present. Thus history became an allegory for aspects of the present. Although the plays dealt with in this article comment overtly on precolonial and colonial times, they were all published in the apartheid era. It stands to reason then that the dramatists of these plays were burning to express their exasperation in some or other way. There was thus a double burden on these historical writers, namely to enact (and add new meaning to) a memorable historical moment, as well as to comment on the present by means of a historical parallel. The monumentalising of a memorable historical moment is very palpable in the plays that seek to recreate aspects of a pre-colonial past, as will be shown later on. But since dramatists were also informed and driven by the circumstances under which they were living, they were often evaluating these circumstances at the same time. The wisdom bestowed by hindsight as well as present needs and desires were thus considerable creative forces in the historical drama in Zulu.

Displaying history in a performative text has also been a way of reclaiming history itself. Under the apartheid regime blacks were also denied the right to tell history from the black point of view. Although restricted in many ways, historical dramatists were claiming the right to tell history from their point of view. Claiming this right goes hand in hand with the issue of identity, because claiming the right to tell one's history is tantamount to claiming one's identity. Although the colonial and apartheid regimes may have seemed keen to acknowledge Zuluness, it was an identity robbed of the privileges, resources, and rights that white identities had claimed for themselves. Indeed, the idea of loss best sums up the driving forces in the historical play in Zulu. Thus, broadly speaking, as the title of the article states, the history play has as its objective the reclaiming of lost ground.

What is a history play? Discussing the beginnings of theatre among Zulu audiences in the early 1900s, Peterson (2000:19) refers to some of the very first plays to be performed in Natal as historical dramas or historical allegories. He mentions plays such as Joseph in Egypt, Job, and Indodana Elahlekayo (The lost son). Further on he 
also discusses 24 plays written by H.I.E. Dhlomo "to order out of the fragmented South African landscape, its silences, tensions and contradictions" (Peterson, 2000:194). The focus in this article is narrower in that it will be directed to published Zulu plays that deal with historical events and persons. Ten of these plays, all of which were published between 1959 and 1993, are full-length plays; one is a one-act play published in a collection of one-act plays, while 27 are published radio plays of Hubert Sishi (Ntuli, 2000). Before the publication of Sishi's plays, history plays constituted about $7 \%$ of the total in Zulu, the most prolific genre being the morality play, at about $40 \%$ (these calculations are my own; see Groenewald, 2002). Sishi's plays would swell the percentage of history plays in Zulu to about $21 \%$. Only 27 of a possible 130 short radio plays that were broadcast between the early 60s and 1985 (Ntuli, 2000:4) were published.

\section{UNodumehlezi kaMenzi - He who is famous as he sits, the son of Menzi (King Shaka)}

Zulu dramatists, writers and artists have reminisced more about King Shaka than about any other king in Zulu history. And rightly so, it could be argued. When Shaka established kwaDukuza, his third umuzi (homestead), in 1824 about 80 kilometres from the present city of Durban, one of Africa's most powerful empires had been established. Four years later, on 24 September 1828, Shaka's reign, which lasted about 12 years, was abruptly ended when he was killed by his half-brothers, Dingane and Mhlangana, and by Mbopha, his trusted official. One play, Ngenzeni? (What have I done? Mncwango, 1959), portrays Shaka as a minor character, while five plays deal with major aspects of Shaka's life, from his coming to power to his death. (Interestingly, Shaka's eventful childhood and youth have not yet been explored in dramatic texts.)

In UNtombazi (Ntombazi - see Dladla, 1979) we see how Shaka eventually catches up with Ntombazi, the head-hunting mother of Zwide, chief of the once-mighty Ndwandwe empire, and puts her to death. In the play there are many pronouncements on ubukhosi (rule), and it becomes clear that the play comments on the use of power by the two leaders, Ntombazi and Shaka. The play opens with a bestial atmosphere as Ntombazi engages in sorcery, and closes at the point at which she is devoured by one of her hyenas, which she had fed on the flesh of her victims. In between, the dramatist sets up a series of contrasts between the young Shaka and the older Ntombazi to compare the moral basis of their 
respective ways of using power. Ntombazi is portrayed as an umthakathi (sorcerer) whose power emanates from evil forces. She plots the instability of the area and collects the heads of neighbouring leaders as trophies. She is described as an oppressor of the region and as a great danger (p. 7). Ntombazi gains more and more power by despicable means. She uses Ntombazana, Zwide's sister, described as "inkosazana yoxolo yakwaNdwandwe" (Ndwandwe the princess of peace, p. 17), to lure Dingiswayo, chief of the Mthethwa clan, to his death. Her reign is one of cruelty (p. 45) and of the shedding of innocent blood (p. 46). By contrast, Dladla portrays Shaka as a dignified leader. Shaka's task is to build a Zulu nation, a task sanctioned by the ancestors (p. 7, 78), not by evil spirits. Shaka is a conqueror, not one who sheds innocent blood (p. 8), a great king who will deliver the people from a reign of oppression (p. 7). To him rule is an important responsibility (p. 11), whereas Ntombazi is driven by sheer ambition, the very thing that leads her to her terrible death. Shortly before her death she delivers the play's message as follows (p. 90):

Nginje nje kungenxa yale mpethu engukulangazela ubukhulu nesikundla. Le mpethu, uMvelinqangi ayifaka ngephutha engqondweni yalowo nalowo muntu ozelwe. Sengifundile, noma ngifunde emva kwendaba, sebugayiwe babila bachitheka bungakavovwa. Sengifundile ukuthi ukulangazelelwa, ubukhulu abuzuzwa kodwa kuyazuza.

(I am in this state as a result of this worm of desire for greatness and position. God placed this worm by accident in the mind of every person that is born. I have learnt, even though too late, the beer having been ground, cooked and spilled before being strained. I have learned that ambition and greatness are not gained; rather, they devour.)

Finally, the heartless Ntombazi, who reigns through terror, is contrasted sharply with a romantic Shaka who has created a paradise for his people, a land of abundance and freedom ("Leli lami yizwe lenala nenkululeko" - This land of mine is a land of abundance and freedom, p. 75). In a long scene (p. 75-78) we encounter a tranquil, amorous Shaka admiring the flowers and listening to the birds while speaking sweet words to his sweetheart Nomaganu. This contrasts starkly with the dramatist's negative depiction of Ntombazi.

In Ngenzeni? (What have I done? Mncwango, 1959) much of the action revolves around the flight of the lovers, Hilwayo and Zenzile, from the wrath of the ruler Menziwa, who has ordered Zenzile (and her twin sister) to his isigodlo ("harem"). But the play is also 
preoccupied with the confrontation between Sikhunyana (also known as Sigujana) and Shaka. Against this background Menziwa is portrayed as a tyrant - at his behest people's possessions are looted, tortured or simply killed. Interestingly, then, the lovers find refuge at Shaka's place, showing that Shaka was, according to the dramatist, a refuge to many people.

KwaBulawayo - Izigameko Zombuso Wenkosi UShaka (At Bulawayo - episodes during Shaka's rule, Gumbi, 1984) and Abelumbi (The Wizards, Gumbi, 1995), present various incidents during Shaka's rule, from the arrival of the whites up to his death. Since these plays are similar - in fact, Abelumbi contains many identical passages - they will be treated together. The title of the play KwaBulawayo is a conspicuous reminder that the historical dramatist in Zulu disregards historical accuracy in favour of ideological sentiment. Shaka only started to encounter white settlers while at his KwaDukuza residence, and not while he resided at KwaBulawayo. In these plays Gumbi makes a fuss about the weirdness of the first white settlers - hence the title Abelumbi - and the superior wisdom of Shaka. While their appearance and culture are endless sources of amusement to Shaka's people (not to Shaka, because the dramatist needs to show that Shaka rises above trivialness), a more telling bit of information is the fact that the whites are always changing (“... umuntu lona ulala uphenduka ..." KwaBulawayo, p. 46). Shaka immediately applies this to Fynn's changing complexion, but one cannot help thinking that the dramatist may have been alluding to swinging moods of authority the dramatist shows how the settlers appear humble before Shaka, but behind his back they harbour less submissive attitudes - all for the sake of gaining access to the rich game resources of the area. These two plays emphasise how Shaka's wisdom is acknowledged by the whites (Abelumbi, p. 31): in fact, they regard him as a genius ("Thina maNgisi umuntu onjalo sithi yijiniyasi" - We English call such a person a genius, p. 70), and how he wants to learn from them because knowledge is power (KwaBulawayo, p. 94). These two plays have the appearance of simple episodic enactments, the aim of which is to put the wisdom of a leader on display, yet they are serious enactments of recuperation. In a time when not only the once-mighty Zulu but all blacks were downtrodden culturally and intellectually, these plays want to reclaim these values, as is clear from the statement ascribed to Fynn by the dramatist:

Mina ngangithi sihlangene nabantu abasesemuva empucukweni abangafundile. Kodwa namhlanje ngibonile ukuthi inkosi uShaka inobuhlakani obukhulu impela (Abelumbi, p. 31). 
(I thought that we have encountered a backward, unlearned people. But today I have seen that King Shaka truly has great wisdom.)

In these two plays there is also an opposition visible: the whites may be abelumbi - those who accomplish strange feats - but Shaka can match this with exceptional wisdom.

In Ukufa KukaShaka (The death of Shaka, Zondi, 1960) we encounter the political Shaka. Ukufa is the shortest full-length play in Zulu, but it is also the densest text. It is thematically rich, contains the richest depiction of Shaka compared to other dramas, and is not marred by unnecessary scenes and dialogue, as are most long plays in Zulu. The play enacts the forces, including Shakan ideals, that led to his death. It gives the most balanced image of Shaka, in that we see, on the one hand, admirable Shakan ideals (or so-called Shakan ideals), but also aspects of the despotic Shaka. Early on in the play, after Mkabayi has sketched the terrible state of the nation and Shaka has ordered the subjugation of smaller groups by taking their cattle, he expresses his desire for African unity:

Ngithanda njengoba sengiqalile nje, ukuba ngibumbe umuntu omnyama abe munye (p. 4,5).

(I would like, as I have already started, to make one united black people.)

This supposedly Shakan ideal must be placed within the historical context in which Zondi was writing his play - the late 1950s. Some aspects of the most incursive apartheid legislation was adopted in the 50s. In 1950 the Group Areas Act was introduced, followed by the Separate Representation of Voters Act in 1956. Nelson Mandela emerged at this time and the Freedom Charter was drawn up in 1955, so that a united front was needed at this time. Zondi paradoxically situates this black nationalistic ideal against the background of some sensitive Shakan practices: of conquering the smaller surrounding chieftaincies (p. 5, 11) in order to become stronger and obtain more wealth (cattle, p. 13), of increasing the strength of his army (p. 4, 11), of obliterating witchcraft, theft and lies (p. 5). All this shaking up - the dramatist uses the ominous word shakazisa (p. 5) - is necessary to heal a sick nation (p. 6) and eventually to create one superpower (p. 12, 27). Another ideal, which was the cry, not only of Zulus in apartheid times, but of every black person, was that of freedom. Zondi introduces the concept into the play (p. 5) when he says he wants to free his people of the slavery of fear and the fear of slavery. This phrase is obviously 
significant in the broader South African context. Shaka also indicates that freedom will not come about automatically (p. 13):

Inkululeko isikhandanisile; ngeke ize kithi, ithina esiyoya kuyona.

(Freedom has already begun; it won't come to us, we must go to it.)

This singular oblique indication that mobilisation is necessary to obtain freedom will become much more forceful in Zondi's second play, Insumansumane (Weird tale - see Zondi, 1986). Of course - to come back to the balance that Zondi dramatises in this play behind Shaka's back Mkabayi, Shaka's aunt, was working towards freedom from his despotic rule (p. 30, 32).

The concept of basic rights is also made relevant as a result of Shaka's subjugation of people. It is very telling that a character such as Mhlangana, Shaka's timid younger half-brother, would suggest to Shaka that a loss of basic rights, such as the right to marry, might jeopardize Shaka's ideal of creating a central government (p. 12). How should a viewer/ reader see this issue of one powerful central government? Was the dramatist longing for a balance of power against the regime that was dismantling South African society, or for unity among and more power for his own ethnic group?

Zondi also raises the issue of land (p. 19) when Shaka states adamantly that the settlers may use the land they are on, but that Shaka will never apportion land to the whites, land which they could claim exclusively.

Most of the dramas in which Shaka is the main character, or a major character, prepare for Shaka's death by enacting the factors that led to his downfall. His death is nevertheless lamented. In Nawe Mbopha KaSithayi (You too, Mbopha of Sithayi, Mbatha, 1971) another lamentable issue is raised, namely that Shaka was killed by one his closest confidants, Mbopha kaSithayi. Mbopha is killed for the part he played, but the dramatist also finds it necessary to put Dingane and especially Mbopha through terrible anguish for betraying a brother and king. Mbatha finds inspiration in Shakespeare's Julius Caesar to create Dingane's and Mbopha's torment. Dingane is tormented by a voice that reminds him of Shaka's curse (p. 55), namely that he will never rule the land. Mbopha torments himself with the thought that he was carried away by his heart - that he did not think straight (p. 64) - and that he was not a true friend to Shaka (p. 65). His dying words are those supposedly spoken by 
Shaka when he died: Nawe Mbopha kaSithayi! (You too, Mbopha of Sithayi! - p. 71), an echo of the famous "Et tu, Brute" in Julius Caesar when Caesar is killed by Brutus and co-conspirators.

\section{Izwe lidungekile - The land is in turmoil}

The rule of Shaka has passed, a rule that would imbue following generations with much pride, a rule that many Zulus would also reminisce on with nostalgia, and see as preferable to the lamentable post-Shakan state. After Shaka the Zulu find themselves in an era of even greater conflict, where the odds against them have become much greater. They now find themselves up against a great, imperialistic empire - the British empire. Not only that, though: another potentially devastating force has emerged, namely internal strife, a topic that makes up most of the content in Mageba Lazihloza (Mageba, it has been fulfilled, Ndelu, 1962). In this play the dramatist enacts the succession struggle between Cetshwayo and his brother Mbuyazi to justify the coming to power of the former as the heir to the Zulu leadership, legitimised by Mlenzemunye (God). And because of this divine calling Cetshwayo could overcome a big obstacle, namely his father Mpande's opposition when he (Mpande's) attempts to appoint Mbuyazi to the throne. After Cetshwayo had won the battle of Ndondakusuka and personally, according to the play, killed Mbuyazi, he holds his father responsible for the bloodshed.

But Cetshwayo's divine calling, and the fact that he prevailed against his father and the forces of Mbuyazi, and even the fact that he and many of his subjects possessed a considerable quantity of guns and ammunition (Laband, 1995:181), could not prevent the beginning of the destruction of the Zulu empire during his rule. In both Uqomisa Mina Nje Uqomisa Iliba (If you court me, you court death, Blose, 1960) and Izulu Eladuma ESandlwana (It thundered at Isandlwana, Msimang, 1976), Cetshwayo's authority is threatened. In Uqomisa Blose creates a dramatic dilemma: Nontombi of the Ngcugce girl's regiment, who has rejected the king's order to marry into the Dlokwe and Ndlondlo regiments, is the daughter of Ngqengelele, a faithful subject of the king. Nontombi and her lover, Maqanda, decide to elope in order to escape the king's injunction, but they pay the ultimate price for their decision. A much greater threat to Cetshwayo's authority would come from outside the boundaries of his kingdom.

Izulu Eladuma ESandlwana deals extensively with issues that led to the fateful time in Zulu history when the Zulu kingdom started to 
crumble as a result of the Anglo-Zulu War in 1879. In this play, where the core issue is sovereignty, Msimang sets up an opposition between the king and the forces challenging his sovereignty. At the beginning of the play the dramatist introduces the disconcerting and unbelievable fact of encroachment by Boer farmers, and King Cetshwayo expresses his exasperation about this incursion as follows (p. 25):

Ngithunge isicoco namhlanje kodwa angizange ngizwe ngisho ezinganekwaneni ukuthi ngoba umuntu usehlome amadlangala ezweni lomunye, lelo zwe akusale sekuba elakhe. Ubusela lobo. Futhi empeleni ukwedelela lokho. Angikaze ngikuzwe futhi ukuthi umuntu angakha ezweni lenkosi kanti ngeke abuswe imithetho yaleyo nkosi akhe ezweni layo. Ukweyisa lokhu.

(I wear a headring today but I have never heard of it, not even in folktales, that just because a person has set up shelter in the land of another, that land has now become his. That is theft. Furthermore it is insolence. I have also never heard of it that a person resides in the country of a king but does not fall under the rule of that king. That is contempt.)

In Ukufa KukaShaka (1960) there is one reference to whites and land; in Izulu it becomes the main theme. Whites are referred to as gluttons intent on usurping all land on which blacks are living (p. 5) an action that would inevitably lead to poverty (p. 2). Cetshwayo has no power against these encroachments: his hands and feet are tied by the whites (p. 6) and he is a stranger in his own land (p. 24). The final showdown between Cetshwayo and the colonial government begins with an ultimatum presented to King Cetshwayo's delegates on the banks of the Thukela River by John Shepstone, Sir Theophilus Shepstone's younger brother, on 9 December 1878 (Laband, 1995:200). Msimang (1976:39, 40) presents six points of the ultimatum while Laband $(1995: 193,194)$ mentions at least nine points. But the important issue is that the king's sovereignty is undermined and his power curbed as he was required to disband his system of amabutho (warriors). The ultimatum expired on 11 January 1879, leading to the war. The threat of bloodshed as suggested by the refrain used by King Cetshwayo throughout the play - "izwe yinto yokufelwa" (the land is something one must die for) - becomes imminent. The outcome of the war is a resounding victory for the Zulus. That Msimang does not dramatise the crucial subsequent battles leading to the demise of the Zulu kingdom is very telling. Msimang's post-colonial longings are clear: to reclaim victory, and with it, dignity for the Zulu nation. And yet Msimang has to acknowledge that the "utopian" pre-colonial/Shakan state is about 
to be shattered irreparably. After the battle at Isandlwana hill (22 January 1879) a warrior anticipates that this [is a] small thing; what comes is much greater "... lokhu okuncane, okukhulu okuzayo ...", p. 86). In a lyric poem the warrior expresses an utopian dream on behalf of many Zulus, namely that if only the nation could march to kwaDukuza (previously known as Stanger, and the symbolic grave site of Shaka) to resurrect Shaka in the hope that he would overturn his curse.

In Izulu the action of the play culminates in war between a kingdom and the colonial government. In the next play we have something more sinister - armed uprising against the government. Insumansumane (Weird tale - see Zondi, 1986), Elliot Zondi's second play and his most radical, since it often suggests the need for an uprising, deals with the Bambada rebellion of 1906 when Bambada of the Zondi clan led an uprising against the colonial government. The uprising was crushed and Bambada killed. More than any other history play in Zulu, Insumansumane is, in my view, reflective of life under the apartheid government. Apart from describing oppressive conditions, Zondi also depicts the dupe who seeks favour with the government in order to attain a leadership position. Zondi uses the Bambada incident to comment on both the conditions that prevailed under the colonial administration and on those that prevailed in the 1980s when he was writing the play. Zondi's central goal is to set up a defiant hero, Bambada, against the colonial government in the midst of an utterly broken Zulu nation. The rebellion came at possibly the darkest time in the history of the Zulu nation. By 1906 Zulu leaders had lost most of their powers, "King" Dinizulu was demoted to "Government Induna and Advisor" (Laband, 1995:433), thousands of young Zulu men had become migrant labourers to earn money for the hut tax, Zululand had become nothing more than a system of black reserves, while yet more of their land $(40,2 \%)$ was set aside for white farmers. The imposition of a poll tax on 8 August 1905 was thus just one of the factors that led to the boiling over of utter frustration. Zululand was festering with dissatisfaction and needed a radical leader, and it came in the person of the defiant Bambada. Bambada's rebellious personality speaks from every word he utters and the action he takes. When, early on in the play, Bambada acknowledges defeat following the Anglo-Zulu War, he bitterly ascribes it to poor strategy on the part of Zulu commanders and not to superiority in warfare on the part of the British. The point is that, for an oppressed people, there is the need to remember that British soldiers were defeated at Isandlwana (p. 6); they can therefore be defeated again. Some of the issues scattered throughout 
other historical plays are worked out with great emotional intensity in Insumansumane. In Shaka's time the cultural issue is portrayed as a curious difference between people (see for instance KwaBulawayo and Abelumbi). In Insumansumane Zondi goes further and lashes out at the lack of cultural knowledge (p. 11), gross cultural disrespect, in fact, utter rudeness (p. 6, 27), inhumane treatment (p. 22), and the use of racist slurs by the whites (the word "amakhafula" referred to by Bambada occurs at least five times in the play: pp. 6 , $14,44,95,97)$. Not only have blacks been conquered in war, their identity has subsequently suffered - Bambada speaks of "amalulwane" (bats, p. 24), meaning an in-between somebody. No wonder Bambada earlier found it necessary to chastise his people about feelings of inferiority: "Thina njengesizwe esimnyama sizibukela phansi sile sithi besiyini" - We as a black nation see ourselves as inferior and ask ourselves what we are (p. 6). Cultural curiosity about the whites gives way to racial intolerance as a result of the persistent negative attitudes of whites, so that Bambada says “... angimthandi umlungu ..." (I don't like the white man, p. 22). The disregard for traditional leadership by the colonial government and the disdain for it by Ndabazabantu, the "native affairs commissioner" in the play, is vividly illustrated by the disparaging words about leadership and leaders uttered by Bambada: leaders are nothing but "izinsila zalo Hulumeni' (body servants of the Government, p. 7), "imisheshelengwana" (sneaking informers, p. 7), "izincelebana" (favourites, p. 11), "amabekwa" (appointees, p. 13), "izikhonzi" (vassals, p. 28). Unlike in Shaka's time when Shaka, according to Bambada (p. 31), loved to discuss matters with his men, the present government regards Zulu leaders as ignorant children.

Bambada also refers to the great social changes that started to occur in Zulu society after the military conquest of the Anglo-Zulu War and the loss of vast tracts of land that had been signed off to Boer farmers. Bambada depicts the suffering of his people in the image of a pot on a huge fire (p. 41). The pot's lid is weighed down by a large stone and inside the pot are his people. (The image also speaks of release if people would join hands and lift the lid.) The pain of forced child labour and the rights of a child comes to the fore (p. 44), while the humiliation and oppressiveness of farm and migrant labour are also illustrated (p. 21) through the character Sigubhu. Sigubhu says he refused to go to the mine to be "buried alive" and to work blindly like a mole. Refusing also to be a farm worker he chose to go to Johannesburg and become an "undishana" (p. 21, ) where he, a respected uncle of a chief, "became a woman" and made the fire, minded cooking pots, washed up and swept, all 
the while being watched over by a "umaqumbane", a woman employee.

Zondi's choice of the historical figure, Bambada, and the circumstances surrounding him and his people was an apt choice for an allegory to comment on some of the oppressive conditions that prevailed in the 1980s under apartheid. Zondi could simply depict a historical situation and it would apply to aspects of apartheid rule without much fear of censure. But Zondi went further: he hinted at the need for an uprising. One of the first such hints is an extremely subtle intertextual reference to a folktale: Bambada asks his listeners (p. 15): "Niyayazi indaba kaBongoza?" (Do you know the story of Bongoza?) Bongoza or Gubudele is the character in a folktale (UGubudele namazimuzimu - Gubudele and the cannibals) and a play having the same title (Ndebele, 1941) in which Gubudele exterminates the cannibals of his area. Soni (1990:103) speculates that the play is an allegory alluding to the conquering of Boers and Canonici (1998:60) maintains that the play constitutes a criticism of the 1936 Land Act. In the course of the play there are more hints until Bambada finally leaves his home for the bush saying (p. 99): "Ngalesi sibhamu sami ngizonqanda amaphumemi azogcweleza isizwe samaZondi." (With this gun of mine I will stop the whites who have come to plunder the Zondis' land.) Again, as in Izulu Eladuma ESandlwana, an inglorious ending is avoided by the dramatist. The dramatist does not depict the infamous death of Bambada, how he was shot and irreverently beheaded. The recuperation of a heroic figure who resisted an oppressive regime was a vital goal for the dramatist in order to give Zulu readers some hope of deliverance. A dead hero becomes part of memory, but rarely brings about real deliverance.

\section{Izwe ngelethu - The land is ours}

On the first page of Awuwelwa UMngeni (The Umngeni is not to be crossed - or: "So far and no further" - Gcumisa, 1993) the magistrate commissioned with "native affairs" announces to the people he has summoned that the matter he has called them for is about land ("Udaba engikubizele lona udaba Iwezwe"). In this play yet another insumansumane (weird tale, p. 7) plays itself out. The play is "a weird tale" in more than one sense. In the foreword the author states at the outset that his work it is not a history book ("akulona ibhuku lomlandu"). Yet, in the dedication that precedes the foreword the author pays tribute to a real person, Mbikwa kaMcanjana kaManyosi kaSigobe kaLubanjana, for his willingness 
to relate the history of the tribe (the Ngwazi people) on which the play is based. And preceding the dedication is, for all intents and purposes, an authentic photograph of Chief Salimani, the main character in the play. Perhaps one has to see the author's disclaimer in the light of the fact that the play is based on oral history and not on a written text, a text that has more status and authority in the eyes of the (Western) world.

The play is about a land grab, by white farmers, backed by the authority of the Shepstone administration. The dramatist describes Somtsewu kaSonzica (Shepstone) as a man of 45 in the didascalies. The events take place during the reign of Dinuzulu, possibly placing the story in 1884, when Dinuzulu became king. Having retired in 1880, Shepstone served for a brief time as governor of Zululand in 1884, by which time he was 67 or 68 . Oral history, on which the events in the play is based, takes note of events, but the finer details of those events are less important - and this accounts for the miscalculation of Shepstone's age. The play is based on a situation that arose when the Umngeni River changed its course so that the question of boundaries arose. According to the play, the Shepstone administration unilaterally decided that tracts of land west of the Umngeni, including the Vimbingwenya area over which Salimani was chief, would cease to be his and would be given to white farmers for commercial use. Another reason for the need for new boundaries given by Zithulele, the magistrate and uNdabazabantu (commissioner for "native affairs"), was that Salimani's cattle were weakening the purity and health of the cattle of the white farmers. The by now familiar sub-themes provide the backdrop to the main theme: the white commissioner is portrayed as one who sees the Zulu as the subjugated "other": in short, the commissioner shows a complete disregard for their humanity in all its social, political and economic implications. A capitalist insumansumane (weird tale) is told to Salimani by the commissioner, namely that by parting with his land and the people on it, Salimani will not only be relieved of social problems, but that the farmers will be able to produce food, which his people will buy. In order to do so, the people will of course have to work for wages and lose their right to farm themselves. The refrain that ran through Izulu, "izwe into yokufelwa" - the land is to die for - appears in this play as well (p. 12). Salimani fights back and retains his right to remain on his land. It is interesting to note that the dramatist places Shepstone in court to hear the verdict. Victory pronounced in the presence of the usurper is sweet indeed. It is quite possible that the play was written 
around Mandela's release in 1990. Gcumisa was anticipating a situation where he could say: "izwe ngelethu".

\section{Conclusion}

In 1966 Jan-Heinz Jahn, reviewing African literature, pronounced as follows:

Was seitdem [from 1955] erscheinen darf, verdient es kaum, Literatur zu heissen: es ist nur Lesestoff für die Unterstufe (quoted by Groenewald, 1982:49).

Jahn was obviously not aware of some key texts that already existed in his time and that protested, albeit in the typically oblique way in which African language texts prefer to work, about colonial and apartheid abuses. African language texts were largely meant for school use, but this is where they were needed. Although they were oblique and full of silences (Gunner, 2000:236, writing on radio serials), they were by no means mute and collaborative. In the perilous times of apartheid, Zulu writers felt the need to restore the dignity of their people and they found an object of pride in Shaka and the Shakan state. The Shakan memory is a retrospective memory that celebrates an ideal state, a pre-colonial utopia, albeit a flawed one. The Shakan memory is also a potent prospective, efficacious memory - it was hoped that the Shakan legacy would at least provide solace under apartheid. It could not serve as a model to deal with adversaries and attain freedom, though, it disqualified itself in this regard through Shaka's curse. Shaka's curse appears in at least five historical plays, always toward the end of the play or at the very end of a play as final will and testament, so to speak, as persistent operative force. It was deemed so powerful that only Shaka himself could break its spell (see Msimang's Izulu Eladuma ESandlwana - The heavens that thundered at Sandlwana, 1976:87) - until the release of Nelson Mandela.

While nationalist Zulu leaders predictably remember a honourable, well-nigh flawless Shaka at Shaka Day ceremonies, dramatists depict an ambivalent Shaka, a Shaka who was utterly heartless and cruel, but who was also exceptionally wise - see for instance how Gumbi has no qualms about dramatizing how Shaka shatters the head of his infant son (KwaBulawayo, p. 106) while also portraying him as a genius (Abelumbi, p. 70). In Ukufa Shaka pardons one conquered leader (the submissive one) while destroying others, and so on. This depiction of the fallibility of heroes would hopefully not be lost on readers of prescribed dramas at school. 
Hindsight is clearly one of the strategies in the construction of a memory in historical plays. Looking back at the life of Shaka, dramatists implicitly lament Shaka's perceived irrational ambition. Had he taken note of Ntombazi's infamous end as a result of her ambition (Dladla, 1979), had he not desired to be higher than the clouds (Zondi, 1960:37), had he made use of bodyguards (Gumbi in KwaBulawayo, p. 79), his fall may not have come so soon. The contemporary slogan "knowledge is power" (p. 94) spoken by Shaka in KwaBulawayo has clearly informed the content of this play to create the wise Shaka, an example to learners today. The heartrending loss of land suffered by the Zulus since Shaka's death, and by blacks in general following the imposition of the Land Act (1913), prompts Zondi (Ukufa, p. 19) to express adamantly in the voice of Shaka that he will never apportion land to the whites which they may own exclusively. The aim of hindsight knowledge is that survivors must learn from the tragedy (White, 1978:61).

Zulu dramatists have taken us through the building of a morally justifiable Zulu empire by Shaka, its dismal destruction, the threat of uprising under oppressive regimes, to the promise of regaining the land. They have chosen the allegory as literary technique, allegories radiating with sentiments of Zulu nationalism, pride, utter frustration, and then back to a sense of hope. By depicting historical events selectively they were able to comment on aspects of the apartheid government. History plays remain useful texts to sensitise students to the workings of the historical text and memory. For the Zulu dramatist it is vital to restore memory in order for a less decentred identity to be constructed. At the same time it is necessary for the scholar to see how the historical play in Zulu uses and misuses historical fact, how the dramatist imbues it with imagination, symbolism and desire (Field, 2001:250).

\section{List of references}

Blose, M.A.J. 1960. Uqomisa Mina Nje Uqomisa lliba. (If you court me you are courting the grave.) Johannesburg : Bona.

Canonici, N.N. 1998. Elements of conflict and protest in Zulu literature. South African Journal of African Languages, 18(3):57-67.

Dladla, A.H. 1979. UNtombazi. (Ntombazi.) Pretoria : Van Schaik.

Field, Sean. 2001. Oral histories. The art of the possible. In: Kaschula, Russel. (ed.) African Oral Literature. Functions in Contemporary Contexts. Claremont, South Africa : New Africa Books. p. 249-256.

Gcumisa, Mlindeli. 1993. Awuwelwa Umngeni. (The Umngeni is not crossed.) Pietermaritzburg : Shooter \& Shuter.

Groenewald, H.C. 2002. A little space in history - some historical perspectives on Zulu theatre. South African Theatre Journal, 16:30-43. 
Groenewald, P.S. 1982. Ist es nur Lesestoff für die Unterstufe? South African Journal of African Languages, 2(2):48-55.

Gumbi, J.N. 1984. KwaBulawayo: Izigameko Zombuso Wenkosi UShaka. (At Bulawayo: Incidents during Shaka's rule.) Alberton : Librarius.

Gumbi, J.N. 1995. Abelumbi. (The Wizards, i.e. The Whites.) Pretoria : Van Schaik.

Gunner, Liz. 2000. Wrestling with the present, beckoning to the past: contemporary Zulu radio drama. Journal of Southern African Studies, 26(2):223-237.

Laband, John. 1995. Rope of Sand. The Rise and Fall of the Zulu Kingdom in the Nineteenth Century. Johannesburg : Jonathan Ball.

Mbatha, S.B.L. 1971. Nawe Mbopha KaSithayi. (You too, Mbopha, son of Sithayi.) Pietermaritzburg : Lincroft Books.

Minkley, Gary \& Rasool, Ciraj. 1998. Orality, memory, and social history in South Africa. In: Nuttall, Sarah \& Coetzee, Carli (eds.). Negotiating the Past: the Making of Memory in South Africa. Oxford : Oxford University Press. p. 89-99.

Mncwango, L.L.J. 1959. Ngenzeni? (What have I done?) Pietermaritzburg : Shuter \& Shooter.

Msimang, C.T. 1976. Izulu Eladuma ESandlwana. (It thundered at Isandlwana.) Pretoria : Van Schaik.

Ndebele, N.N.T. 1941. UGubudele Namazimuzimu. (Gubudele and the cannibals.) Johannesburg : University of the Witwatersrand Press.

Ndelu, B.B. 1962. Mageba, Lazihlonza. (Mageba, it has been fulfilled.) Pietermaritzburg : Shuter \& Shooter.

Ntuli, D.B. 1987. Writers in shackles? In: Malan, Charles (ed.) Race and Literature/Ras en literatuur. Pinetown : Owen Burgess. p. 127-138.

Ntuli, D.B.Z. 2000. (ed.) Imilando YaKwaZulu. Imidlalo Yomsakazo. Pretoria : University of South Africa.

Peterson, Bhekizizwe. 2000. Monarchs, Missionaries, and African Intellectuals. African Theatre and the Unmaking of Colonial Marginality. Johannesburg : Witwatersrand University Press.

Phafoli, L.S. 1996. Reflection of History in Khaketla's Dramas - A Comparative Analysis. Johannesburg : University of the Witwatersrand. (M.A. dissertation.)

Soni, S.J. 1990. A General Survey of Zulu Drama with a Critical Analysis of Selected Plays. Durban : University of Natal. (M.A. dissertation.)

White, Hayden. 1978. Tropics of Discourse. Essays in Cultural Criticism. Baltimore, London : Johns Hopkins University Press.

Zondi, Elliot. 1960. Ukufa KukaShaka. (The death of Shaka.) Johannesburg : Witwatersrand University Press.

Zondi, 1986. Insumansumane. (An absurd tale.) Johannesburg : Witwatersrand University Press.

Zondi, Elliot. 1989. Zulu Historical Drama. A Critical Analysis of Six Historical Dramas. Durban : University of Natal. (M.A. dissertation.) 


\section{Key concepts:}

historical drama

memory - retrospective

reconstruction of historical facts

Zulu drama

Kernbegrippe:

herinnering - retrospektief

historiese drama

rekonstruksie van historiese feite

Zoeloe-drama 
